doi: https://doi.org/10.15407/dopovidi2018.04.074

UDK 548.4:550.4:549.514.51:553.271.1:552.321 (99)

\author{
I.M. Naumko ${ }^{1}$, G.V. Artemenko ${ }^{2}$, V.G. Bakhmutov ${ }^{3}$, \\ O.P. Vovk ${ }^{4}$, L.F. Telepko ${ }^{1}$, B.E. Sakhno ${ }^{1}$ \\ ${ }^{1}$ Institute of Geology and Geochemistry of Combustible Minerals of the NAS of Ukraine, Lviv \\ ${ }^{2}$ M.P. Semenenko Institute of Geochemistry, Mineralogy and Ore Formation of the NAS of Ukraine, Kiev \\ ${ }^{3}$ S.I. Subbotin Institute of Geophysics of the NAS of Ukraine, Kiev \\ ${ }^{4}$ Lesya Ukrainka Eastern European National University, Lutsk \\ E-mail: igggk@mail.lviv.ua, regul@igmof.gov.ua, bakhm@igph.kiev.ua, geologygeochemistry@gmail.com
}

\title{
Quartz forming conditions in secant veins in granodiorites of the Andean intrusive complex of the Barchans Islands (Argentine Islands, West Antarctic)
}

Presented by Academician of the NAS of Ukraine O.M. Ponomarenko

It is established that the growth of quartz in veins in granodiorites of the Andean intrusive complex (the Barchans Islands, West Antarctic) happened in rock crystal-bearing veins of steep falling, in which the temperature difference necessary for the dissolution of massive quartz and crystallization of its transparent variety in the shape of perfectly cut crystals in central parts of secant veins was reached. The discovered enrichment of the fluid medium of the quartz crystallization with $\mathrm{CO}_{2}, \mathrm{NaCl}$, and $\mathrm{KCl}$ indicates a carbonate-haloid composition of quartz-forming fluids, which favoured the formation of jewelry and technologically perfect crystals, possibly having piezoelectric properties similar to crystals of quartz both from rock-crystal-bearing veins of the Near-polar Ural and those synthesized under laboratory conditions. As a conclusion, the connection of quartz-forming fluids and the postmagmatic processes in a granodiorite intrusion is justified, and the view of investigated quartz veins as formations of post-tectonic hydrothermal stage is confirmed and expanded.

Keywords: quartz, crystal morphology, fluid inclusions, volatile components, secant veins, granodiorites, the Barchans Islands, West Antarctic.

The Antarctic Peninsula block in the Western Antarctica has traditionally been considered as a magmatic arc formed along the south-western part of the Paleo-Pacific subregion during the collapse of the Gondwana supercontinent. About $80 \%$ of the rocks of the Western Antarctica and the adjacent Bellingshausen Sea shelf area are represented by two groups of rocks - the intrusions of the batholiths of the Antarctic Peninsula (AP batholiths), also known as Andean Intrusive Suite rocks, and Volcanogenic rocks of the Antarctic Peninsula [1-3]. Intrusive rocks of the Antarctic Peninsula are gabbro and granitoids (with prevalence of granodiorites). The age of their formation in the studied region ranges from 105 to 84 million years ago [4, 5]. A group of volca(C) I.M. Naumko, G.V. Artemenko, V.G. Bakhmutov, O.P. Vovk, L.F. Telepko, B.E. Sakhno, 2018 
nogenic rocks represented by lavas and tuffogeneous rocks is traditionally assigned to the Upper Jurassic (188-153 million years ago) [5].

Our work scope includes the Barchans Islands $\left(65^{\circ} 15^{\prime} \mathrm{S}, 64^{\circ} 15^{\prime} \mathrm{W}\right)$ located in the western part of the Argentine Islands archipelago in a vicinity of the Ukrainian Antarctic station "Academician Vernadsky". The group of the Barkhans Islands includes three relatively large islands (sized about $0.5 \mathrm{~km}^{2}$ each) and several dozens of small islands (sized from several to tens of $\mathrm{m}^{2}$ ). They are composed of granodiorites of the Andean intrusive complex. On the Barkhans islands, there exists a series of quartz veins up to $10 \mathrm{~m}$ thick that cut through the granodiorite of the Andes complex (azimuth -75 degrees North-East, the angle of incidence -68 degrees). In the veins of white effluent quartz, there are concentrations of ore minerals sized up to $10 \mathrm{x} 15 \mathrm{~cm}$. They were first described in work [6], in which it was noted that ore minerals are found in the veins magnetite, pyrite, epidote.

In the course of field expeditionary studies, samples from secant veins of white massive quartz were collected, in which single nests with perfectly cut crystals of transparent quartz occur [7].

The collected crystals of quartz became the object of complex mineralogical-genetic and thermobarogeochemical-mineralfluidological studies, the results of which allowed one to determine the peculiarities of quartz-forming fluids.

The crystal morphology of quartz was studied, using a two-pointed goniometer GD-1 according to the method in [8]. X-ray analysis was performed on a diffractometer ADP-2.0, Fe $K_{\alpha}$ radiation, Mn-filter; conditions of shooting: $\mathrm{I}=14 \mathrm{~mA}, \mathrm{U}=34 \mathrm{kV}$, meter speed 2 degrees $/ \mathrm{min}$ (analyst Ya.V. Yaremchuk, the X-ray laboratory of the Department of geochemistry of sedimentary strata of oil and gas provinces of IGGGK of the NAS of Ukraine, Lviv). The content of impurities was determined by the spectral method (analyst R. P. Kozak, Laboratory of geoecology problems of IGGGK of the NAS of Ukraine, Lviv). The aggregate state and the homogenization temperature of inclusions in quartz were determined by the thermometric method [9]. Composition of volatile components, their relative gas saturation (increase of the pressure in the inlet system of a mass spectrometer relative to its residual value of the order of $1 \cdot 10^{-3} \mathrm{~Pa}$ in the grinding chamber $(\Delta P), \mathrm{Pa}$ ), and water saturation (water vapor content in the total volume of volatile components $\left(C_{\mathrm{H}_{2} \mathrm{O}}\right)$, vol. \%) were determined by the mass-spectrometric chemical method (device MSH-3A) (analyst B. E. Sakhno, Laboratory of mass-spectrometric chemical analysis of the Department of Geochemistry of deep fluids, IGGGK of the NAS of Ukraine, Lviv). The inclusions were exposed by crushing the standard sample of $200 \mathrm{mg}$, a fraction of $+1-2 \mathrm{~mm}$ in a small metal cylindrical mortar between two planar parallel pobedit surfaces (sintered carbide) under high vacuum $\left(1 \cdot 10^{-3} \mathrm{~Pa}\right)$.

The examined quartz crystals are transparent, with shiny surfaces of facets and the hatching and onflows clearly visible on them and clear images of edges. They possess prismatic habitus and elongated shape and are characterized by a perfect cut (Fig. 1). Traditional simple forms such as a hexagonal prism $\{10 \overline{1} 0\}$ and two rhombohedra $\{10 \overline{1} 1\}$ and $\{01 \overline{1} 1\}$ (Fig. 2) are established. External symmetry of the individuum $-P(m)$ - indicates its growth in rock-crystalline nests of steep falling [10] as an important prerequisite for the reproduction of a possible direction of the inflow of quartz-forming fluids. The "lower" part of the crystal is damaged, the head is absent, apparently, as a result of the attachment to the host rock. Four facets of the hexagonal prism can be observed, two are missing. One of these (missing) facets attached the polyhedron to the rock, 


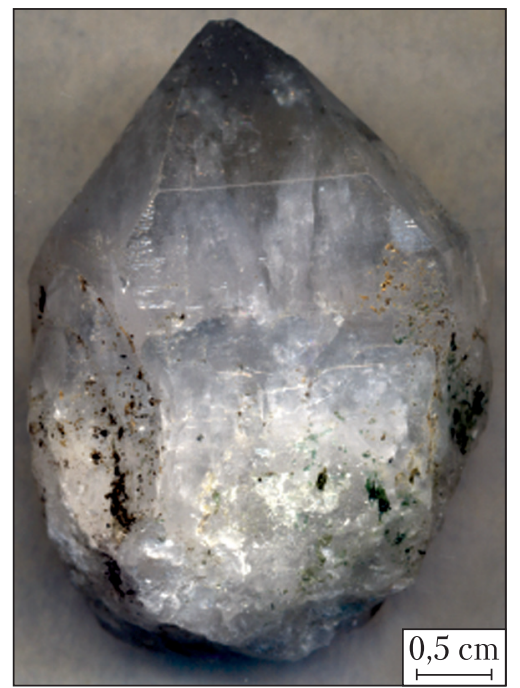

Fig. 1. General view of the quartz crystals from veins in granodiorites and diorites of the Andean intrusive complex (sample Q-142/12/1)

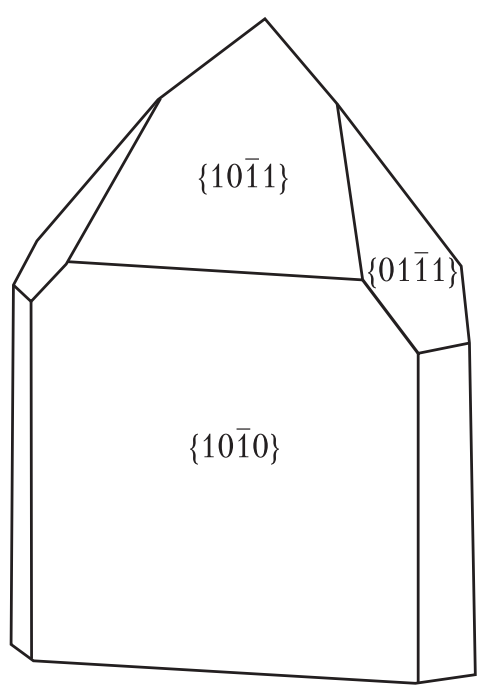

while, on the other facet, two small crystals of quartz grew in parallel, on which only rhombohedron $\{01 \overline{1} 1\}$ is observed. The largest facet of the prism is covered with a traditional quartz hatching perpendicular to $\mathrm{L}_{3}$ and with onflows elongated in the same direction that overlap onto rhombohedron $\{10 \overline{1} 1\}$. On both rhombohedra, all (for one-headed individuum) facets are present. Facets $\{01 \overline{1} 1\}$ are smoother than $\{10 \overline{1} 1\}$. Occasionally, there is a blunt edge between facets $(10 \overline{1} 0)$ i ( $1 \overline{1} 01)$, which, however, can not be considered as a facet.

The results of X-ray analysis (Fig. 3) indicate a quite high chemical purity of the investigated quartz, which is confirmed by the data of the spectral analysis (mass. \%): $\mathrm{Zr}-<0.001$, $\mathrm{Co}-<0.001, \mathrm{Fe}-0.11, \mathrm{~Pb}-<0.001, \mathrm{Be}-<0.0001$, Sn $-<0.001, \mathrm{Cu}-<0.001, \mathrm{Ba}-0.004$, $\mathrm{Sr}-<0.003, \mathrm{Ag}-0.000$.

Quartz crystals are saturated with fluid inclusions of various genetic types, in particular, gas-liquid, complex with a visible phase of liquid $\mathrm{CO}_{2}$, and multiphase ones with captured minerals (daughter minerals) (Fig. 4, $a-c$ ). Inclusions are located mostly in the planes of cracks or dispersed in separate groups (swarms).

Two-phase gas-liquid and liquid-gas inclusions (see Fig. 4, $a$ ) are more prevalent; less frequent are single-phase predominantly gas or liquid inclusions. The latter are often segments separated from the main vacuole due to the dissociation or repositioning of mineral matter on the walls of inclusions. Some of them contain a solid xenogenic phase. The shape of inclusions is varied: oval, elongated, angular, irregular, and with "torn" jagged edges. They reach considerable sizes (more than $0.01 \mathrm{~mm}$ ). Some vacuoles have the shape of perfectly cut negative crystals, or their fragments. The most common temperatures of homogenization of gas-liquid inclusions are the intervals $220-250,250-270,270-300^{\circ} \mathrm{C}$, and the highest temperature reaches $370{ }^{\circ} \mathrm{C}$ (into the liquid phase). This corresponds to temperatures without correction for pressure, which will be absent in the case of a likely heterogeneous state of the fluid medium of mineralogenesis.

Complex inclusions with the visible phase of liquid $\mathrm{CO}_{2}$ are three-phase, have mixedcontent, and are of the type $\mathrm{L}$ (solution) $+\mathrm{L}_{1}$ (liquid $\left.\mathrm{CO}_{2}\right)+\mathrm{G}($ gas $)=5-15+30-40+45-55\left(\right.$ at $+12{ }^{\circ} \mathrm{C}$ ) (see Fig. 4, $b$ ). 


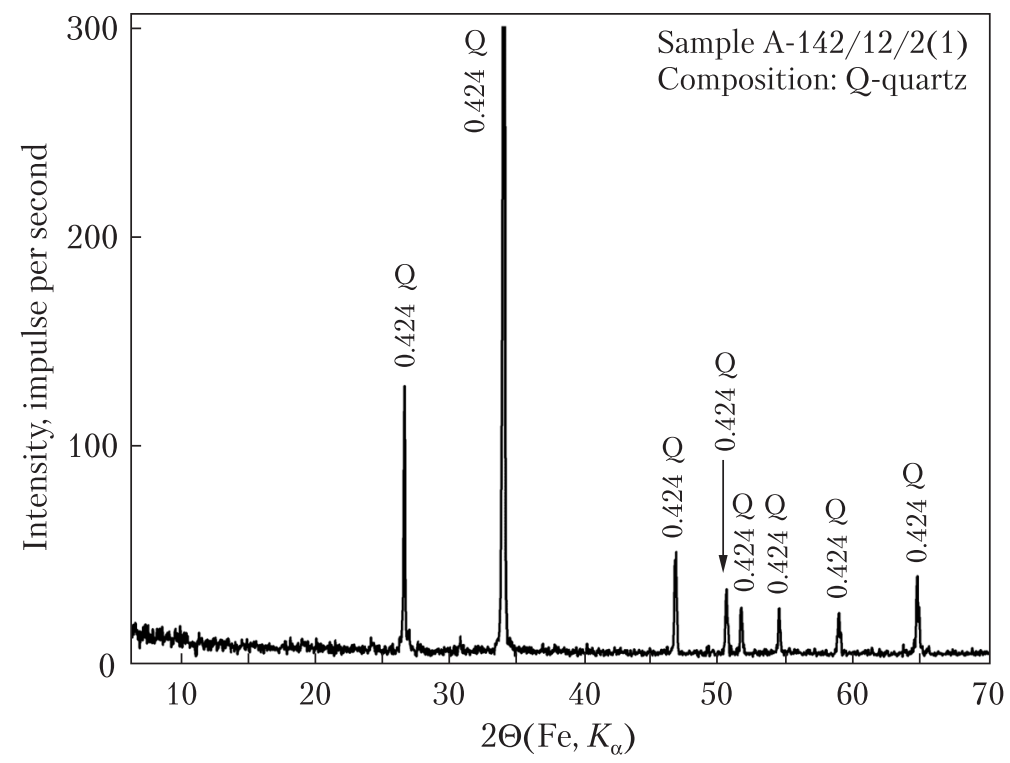

Fig. 3. Diffractogram of quartz

Composition of the volatile components of fluid inclusions in quartz from veins in granodiorites of the Andean intrusive complex of the Barchans Islands (Argentine Islands, West Antarctic) (according to the data from mass-spectrometric chemical analysis ${ }^{1}$ )

\begin{tabular}{|c|c|c|c|c|c|c|c|}
\hline \multirow[t]{2}{*}{$\begin{array}{l}\text { Sample } \\
\text { number }\end{array}$} & \multirow[t]{2}{*}{$\begin{array}{c}\text { Place } \\
\text { of the selection }\end{array}$} & \multirow[t]{2}{*}{$\begin{array}{c}\text { Title } \\
\text { of mineral }\end{array}$} & \multicolumn{2}{|c|}{$\begin{array}{c}\text { Components }^{2}: \\
\text { Voluminous particle, } \\
\text { per cent / } \\
\text { Mass concentration, } \\
n \cdot 10^{-6} \mathrm{~g} / \mathrm{g} \text { of sample }\end{array}$} & \multirow[t]{2}{*}{$\begin{array}{l}\text { Relative } \\
\text { gas } \\
\text { saturation } \\
\Delta P, \mathrm{~Pa}^{3}\end{array}$} & \multirow[t]{2}{*}{$\begin{array}{c}\text { Water } \\
\text { saturation } \\
C_{\mathrm{H}_{2} \mathrm{O}} \text {, vol. \% }\end{array}$} & \multirow[t]{2}{*}{$\begin{array}{c}\text { Total mass } \\
\text { concentration, } \\
n \cdot 10^{-6} \mathrm{~g} / \mathrm{g} \\
\text { of sample }\end{array}$} \\
\hline & & & $\mathrm{CO}_{2}$ & $\mathrm{~N}_{2}$ & & & \\
\hline A-142/12/2 (1) & $\begin{array}{l}\text { Quartz vein, } \\
\text { the Barchans } \\
\text { Islands }\end{array}$ & $\begin{array}{l}\text { Quartz, cent- } \\
\text { er of crystal }\end{array}$ & $97.5 / 293,8$ & $2.5 / 0,08$ & 1.27 & 52.4 & 293.88 \\
\hline A-142/12/2 (2) & Ibid & $\begin{array}{l}\text { Quartz, pe- } \\
\text { riphery of } \\
\text { crystal }\end{array}$ & $98.9 / 177,0$ & $1.1 / 0.01$ & 1.13 & 47.0 & 177.01 \\
\hline
\end{tabular}

1 Analyst B.E. Sakhno (mass-spectrometer MCX-3A).

2 Sample of quartz of the standard weight of $200 \mathrm{mg}$ and fraction $+1-2$ was crushed by squashing in a specially designed mortar, before the analysis, the inlet system of the mass-spectrometer was evacuated to values of order $1 \cdot 10^{-3} \mathrm{~Pa}$.

${ }^{3}$ Relative gas saturation $\Delta P, \mathrm{~Pa}-$ increase of the pressure in the inlet system of a mass spectrometer (with respect to the residual pressure of order $1 \cdot 10^{-3} \mathrm{~Pa}$ in it), which is created as a result of the release of volatile components (without taking into account the steam sorbed on $\mathrm{P}_{2} \mathrm{O}_{5}$ placed in the inlet system) from inclusions and closed pores in the chopping of the sample and may be a comparative value for the same weight.

${ }^{4}$ Relative water saturation $C_{\mathrm{H}_{2} \mathrm{O}}$, vol. \% - percentage of the steam that was absorbed on $\mathrm{P}_{2} \mathrm{O}_{5}$ placed in the intel system, in the total volume of released volatile components.

5 To determine the mass concentration, the crushed analyzed sample was sifted through a 0.25 -mm sieve, and the results were attributed to the sieved portion of the sample. 

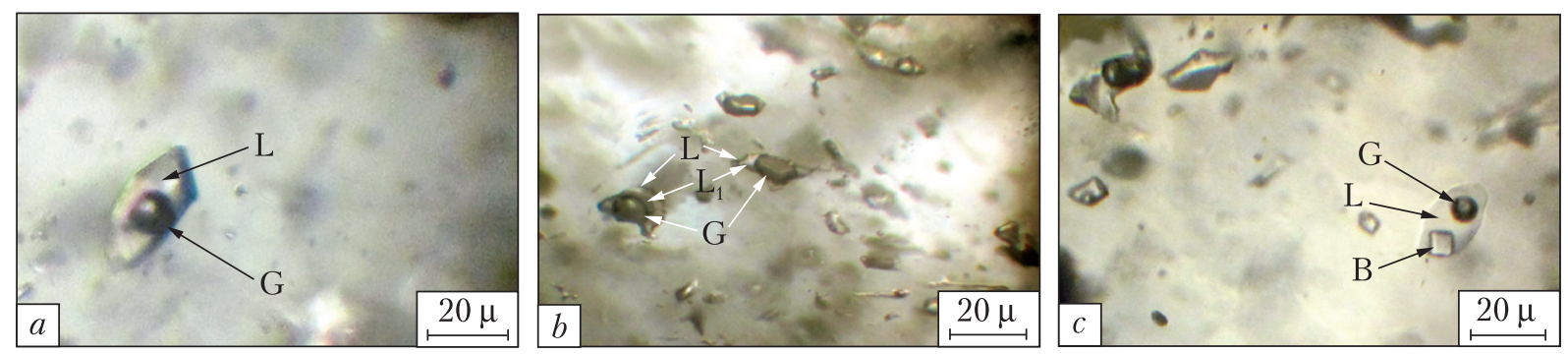

Fig. 4. Fluid inclusions of various genetic types in quartz: $a-$ two-phase gas-liquid inclusion, volumic, with fragments of perfectly cut negative crystals. Temperature of homogenization is $290{ }^{\circ} \mathrm{C}$ (into the liquid phase); $b$ - complex inclusions with the visible phase of liquid $\mathrm{CO}_{2}$ of type $\mathrm{L}$ (solution) $+\mathrm{L}_{1}$ (liquid $\mathrm{CO}_{2}$ ) $+\mathrm{G}$ (gas); $c$-multiphase gas-liquid inclusion with an authigenic solid phase - captured mineral (daughter mineral) (crystal of salt $-\mathrm{NaCl}$ ?). Temperature of crystal dissolution is $220{ }^{\circ} \mathrm{C}$, temperature of complete homogenization is $270{ }^{\circ} \mathrm{C}$ (into the liquid phase)

The particular attention is drawn to multiphase inclusions with an authigenic solid phase represented by one or (much rarely) two crystals of a salt, probably (as our experience shows [11, 12]), captured minerals (daughter minerals) $-\mathrm{NaCl}$ and $\mathrm{KCl}$ ) (see Fig. 4, c). This solid phase $\left(\mathrm{NaCl}\right.$ ?) in one of the inclusions dissolves at $220^{\circ} \mathrm{C}$, and the complete homogenization of an inclusion is achieved at $270{ }^{\circ} \mathrm{C}$ (into the liquid phase).

According to data from the mass-spectrometric chemical analysis, the composition of the volatile components of inclusions in quartz is characterized by the clear prevalence of carbon dioxide (97.5-98.9 vol. \%) over nitrogen (1.1-2.5 vol. \%) (Table). The samples have high relative gas saturation (1.13-1.27 Pa), water saturation (47.0-52.4 vol. \%), and total mass concentration $\left(177.01-293.88 \cdot 10^{-6} \mathrm{~g} / \mathrm{g}\right.$ of sample).

The above numbers indicate fairly high temperatures and the carbon dioxide-water composition of quartz-forming fluids. At the mentioned temperatures of the order of $300{ }^{\circ} \mathrm{C}$, the fluid became capable of transferring a significant amount of dissolved components, in particular silica-containing ones. The growth of perfect crystals was carried out in in rock crystal-bearing veins of steep falling, in which the temperature difference required for the dissolution of massive quartz and the crystallization of its transparent variety in the shape of perfectly cut crystals in the central parts of the quartz vein was achieved. The coexistence of multiphase inclusions with crystals of salts and complex inclusions with the visible phase of liquid $\mathrm{CO}_{2}$ confirms the highly concentrated nature of a fluid, which is separated from the magmatic source, with a significant carbon dioxide content. This conclusion follows logically from the analysis of experimental data [13] on the homogeneous state of a complex system of $\mathrm{H}_{2} \mathrm{O}-\mathrm{CO}_{2}-\mathrm{NaCl}$ at a high temperature, its separation during the heterogenization into $\mathrm{NaCl}$ or $\mathrm{CO}_{2}$-enriched components, and spatial-temporal difference of their manifestation.

Thus, according to the study of inclusions, the enrichment in $\mathrm{CO}_{2}, \mathrm{NaCl}$, and $\mathrm{KCl}$ of the fluid medium of crystallization of quartz, similar to the rock-crystalline veins of the Near-polar Ural, indicates the carbonate-haloid composition of quartz-forming fluids during the formation of the investigated mineral, which contributed to the formation of jewelry and technologically perfect crystals, possibly having piezoelectric properties. It should be noted that, under labora- 
tory conditions, very high quality quartz crystals were synthesized from aqueous solutions of hydroxides and carbonates of alkali metals within a similar interval of temperatures and in the presence of a corresponding temperature gradient [14, 15].

The obtained data indicate the connection of quartz-forming fluids with postmagmatic processes in the granodiorite intrusion and confirm and expand the idea of the investigated quartz veins as formations of the post-tectonic hydrothermal stage [7].

\section{REFERENCES}

1. Grikurov, G. E. (1973). The geology of the Antarctic Peninsula. Moscow: Nauka (in Russian).

2. Leat, P. T., Scarrow, J. H. \& Millar, I. L. (1995). On the Antarctic Peninsula batholith. Geol. Mag., 132. Iss. 4, pp. 399-412.

3. Bakhmutov, V. G. (1998). Geological review of Argentine islands archipelago and adjoining territory of the Antarctic Peninsula. Bull. UATs, Vyp. 2, pp. 77-84 (in Russian).

4. Bakhmutov, V. G., Gladkochub, D. P. \& Shpyra, V. V. (2013). Age position, geodynamic specific and paleomagnetism of intrusive complexes of the western sea coast of the Antarctic Peninsula. Geophys. J., 35, No. 3, pp. 3-30 (in Russian).

5. Pankhurst, R. J., Riley, T. R., Fanning, C. M. \& Kelley, S. P. (2000). Episodic silicik volcanism in Patagonia and the Antarctic Peninsula: Chronology of magmatism associated with the break-up of Gondwana. J. Petrol., 41, Iss. 5, pp. 605-625.

6. Elliot, D. H. (1964). The petrology of the Argentine islands. British Antarctic surv. Sci. reports, No. 41, pp. $1-31$.

7. Artemenko, G. V., Bakhmutov, V. G., Samborskaia, I. A. \& Kanunikova, L. I. (2011). Manifestations of the ore mineralization in the intrusive complex of the archipelago Argentine islands, West Antarctica. Mineral. J. (Ukraine), 33, No. 3, pp. 90-99 (in Russian).

8. Vovk, O. P. (2016). Crystal morphology of topaz and beryl of chamber pegmatites of Korosten' pluton (northwestern part of the Ukrainian Shield). (Extended abstract of candidate thesis). M.P. Semenenko Institute of Geochemistry, Mineralogy and Ore Formation of the NAS of Ukraine, Kiev, Ukraine (in Ukrainian).

9. Kalyuzhnyi, V. A. (1982). Principles of knowledge on mineral-forming fluids. Kiev: Naukova dumka (in Russian).

10. Shaphranovskiy, I. I. (1974). Essays over the mineralogical crystallography. Leningrad: Nedra (in Russian).

11. Naumko, I., Zinchuk, I., Kalyuzhnyi, V. \& Red'ko, L. (2005). Multiphase fluid inclusions with captive minerals: formation, preservation, interpretation and application with the purpose of forecasting and prospective estimating. In Mineralogical Museum (pp. 223-224). Saint-Petersburg: Department of Mineralogy SPbSU (in Russian).

12. Naumko, I. M. (2006). Fluid regime of mineral genesis of the rock-ore complexes of Ukraine (based on inclusions in minerals of typical parageneses). (Extended abstract of Doctor thesis). Institute of Geology and Geochemistry of Combustible Minerals of the NAS of Ukraine, Lviv, Ukraine (in Ukrainian).

13. Takenouchi, S. \& Kennedy, G. C. (1965). The solubility of carbon dioxide in NaCl solutions at high temperatures and pressures. Amer. J. Sci., 263. No. 5, pp. 445-454.

14. Balitskiy, V. S. (1978). Experimentic investigation of processes of the cut-glass formation. Moscow: Nedra (in Russian).

15. Balitskiy, V. S. \& Lisitsyna, Ie. Ie. (1981). Synthetic analogues and immitations of nature gem stones. Moscow: Nedra (in Russian).

Received 26.12.2017 
I.М. Наумко ${ }^{1}$, Г.В. Артеменко ${ }^{2}$, В.Г. Бахмутов ${ }^{3}$, О.П. Вовк ${ }^{4}$, Л.Ф. Телепко ${ }^{1}$, Б.Е. Сахно ${ }^{1}$

${ }^{1}$ Інститут геології і геохімії горючих копалин НАН України, Львів

${ }^{2}$ Інститут геохімії, мінералогії та рудоутворення ім. М.П. Семененка НАН України, Київ

${ }^{3}$ Інститут геофізики ім. С.І. Субботіна НАН України, Київ

${ }^{4}$ Східноєвропейський національний університет ім. Лесі Українки, Луцьк

E-mail: igggk@mail.lviv.ua, regul@igmof.gov.ua, bakhm@igph.kiev.ua, geologygeochemistry@gmail.com

УМОВИ ФОРМУВАННЯ КВАРЦУ В СІЧНИХ ЖИЛАХ У ГРАНОДІОРИТАХ АНДСЬКОГО ІНТРУЗИВНОГО КОМПЛЕКСУ ОСТРОВІВ БАРХАНИ (АРГЕНТИНСЬКІ ОСТРОВИ, ЗАХІДНА АНТАРКТИКА)

Встановлено, що ріст жильного кварцу в гранодіоритах андського інтрузивного комплексу (острови Бархани, Західна Антарктида) здійснювався у кришталеносних жилах крутого падіння, в яких досягався перепад температури, необхідний для розчинення масивного кварцу і кристалізації його прозорого різновиду у вигляді прекрасно огранених кристалів у центральних частинах січних жил. Виявлена збагаченість флюїдного середовища кристалізації кварцу $\mathrm{CO}_{2}, \mathrm{NaCl}$ і $\mathrm{KCl}$ вказує на карбонатно-галоїдний склад кварцутворювальних флюїдів, що сприяло формуванню ювелірно і технологічно досконалих кристалів, можливо, $з$ п'єзоелектричними властивостями, подібно до кристалів кварцу, як кришталеносних жил Приполярного Уралу, так і синтезованих у лабораторних умовах. У підсумку обгрунтовано зв’язок кварцутворювальних флюїдів та постмагматичних процесів у гранодіоритовій інтрузії і підтверджено та розвинено точку зору на вивчені кварцові жили як на утворення посттектонічної гідротермальної стадії.

Ключові слова: квари, кристаломорфологія, флюїдні включення, леткі компоненти, січні жили, гранодіорити, острови Бархани, Західна Антарктика.

И.М. Наумко ${ }^{1}$, Г.В. Артеменко ${ }^{2}$, В.Г. Бахмутов ${ }^{3}$, А.П. Вовк ${ }^{4}$, Л.Ф. Телепко ${ }^{1}$, Б.Э. Сахно ${ }^{1}$

${ }^{1}$ Институт геологии и геохимии горючих ископаемых НАН Украины, Львов

${ }^{2}$ Институт геохимии, минералогии и рудообразования им. М.П. Семененко НАН Украины, Киев

${ }^{3}$ Институт геофизики им. С.И. Субботина НАН Украины, Киев

${ }^{4}$ Восточно-Европейский национальный университет им. Леси Украинки, Луцк

E-mail: igggk@mail.lviv.ua, regul@igmof.gov.ua, bakhm@igph.kiev.ua, geologygeochemistry@gmail.com

\section{УСЛОВИЯ ФОРМИРОВАНИЯ КВАРЦА В СЕКУЩИХ ЖИЛАХ В ГРАНОДИОРИТАХ АНДСКОГО ИНТРУЗИВНОГО КОМПЛЕКСА ОСТРОВОВ БАРХАНЫ (АРГЕНТИНСКИЕ ОСТРОВА, ЗАПАДНАЯ АНТАРКТИКА)}

Установлено, что рост жильного кварца в гранодиоритах андского интрузивного комплекса (острова Барханы, Западная Антарктида) осуществлялся в хрусталеносных жилах крутого падения, в которых достигался перепад температуры, необходимый для растворения массивного кварца и кристаллизации его прозрачной разновидности в виде прекрасно ограненных кристаллов в центральных частях секущих жил. Выявленное обогащение флюидной среды кристаллизации кварца $\mathrm{CO}_{2}, \mathrm{NaCl}$ и $\mathrm{KCl}$ указывает на карбонатно-галоидный состав кварцобразующих флюидов, что способствовало формированию ювелирно и технологически совершенных кристаллов, возможно, с пьезоэлектрическими свойствами, подобно кристаллам кварца, как хрусталеносных жил Приполярного Урала, так и синтезированных в лабораторных условиях. В итоге обоснована связь кварцобразующих флюидов и постмагматических процессов в гранодиоритовой интрузии и подтверждена и развита точка зрения на изученные кварцевые жилы как на образования посттектонической гидротермальной стадии.

Ключевые слова: квари, кристалломорфология, флюидные включения, летучие компоненты, секущие жиль, гранодиориты, острова Барханы, Западная Антарктика. 